Revista Brasileira de Farmacognosia Brazilian Journal of Pharmacognosy 22(1): 150-156, Jan./Feb. 2012

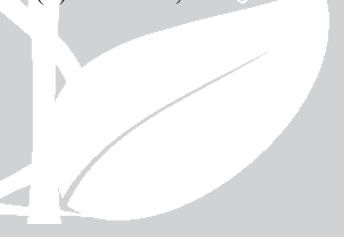

Article

Received 16 Dec 2010

Accepted 28 Jul 2011

Available online 14 Oct 2011

Keywords:

Mikania lindleyana

anti-inflammatory

antinociceptive

Asteraceae

sucuriju

phytomedicine

ISSN 0102-695X

http://dx.doi.org/10.1590/S0102-

695X2011005000190

\section{Anti-inflammatory and opioid-like activities in methanol extract of Mikania lindleyana, sucuriju}

\author{
Frederico A. Vanderlinde, ${ }^{* 1}$ Fabio F. Rocha, ${ }^{1}$ David C. Malvar, ${ }^{1}$ \\ Raquel T. Ferreira, ${ }^{1}$ Elson A. Costa, ${ }^{2}$ Iziara F. Florentino, ${ }^{2}$ \\ Giselle M. S. P. Guilhon, ${ }^{3}$ Thereza C. M. de Lima ${ }^{4}$
}

\author{
${ }^{1}$ Departamento de Ciências Fisiológicas, Instituto de Biologia, Universidade \\ Federal Rural do Rio de Janeiro, Seropédica, Brazil, \\ ${ }^{2}$ Departamento de Ciências Fisiológicas, Instituto de Ciências Biológicas, \\ Universidade Federal de Goiás, Goiânia, Brazil, \\ ${ }^{3}$ Departamento de Química, Centro de Ciências Exatas e Naturais, Universidade \\ Federal do Pará, Brazil, \\ ${ }^{4}$ Departamento de Farmacologia, Universidade Federal de Santa Catarina, Brazil.
}

\begin{abstract}
Mikania lindleyana DC., Asteraceae (sucuriju), grows in the Amazon region, where is frequently used to treat pain, inflammatory diseases and scarring. This study was carried out to investigate phytochemical profile accompanied by in vivo antinociceptive and anti-inflammatory screening of $n$-hexane (HE), dichloromethane (DME) and methanol (ME) extracts obtained from the aerial parts of the plant. The oral administration of $\operatorname{ME~}(0.1,0.3,1 \mathrm{~g} / \mathrm{kg})$ caused a dose-related reduction $(16.2,42.1$ e $70.2 \%)$ of acetic acid-induced abdominal writhing while $\mathrm{HE}$ and DME $(1 \mathrm{~g} / \mathrm{kg}$, p.o. $)$ were ineffective. In the hot plate test, ME $(300 \mathrm{mg} / \mathrm{kg}$, p.o.) increased the latency of heat stimulus between 30 and $120 \mathrm{~min}$ and inhibited the first $(45 \%)$ and second $(60 \%)$ phases of nociception in the formalin test. The antinociception induced by ME or positive control fentanyl $(150 \mu \mathrm{g} / \mathrm{kg}$, s.c. $)$ in hot plate and formalin tests was prevented by naloxone $(3 \mathrm{mg} / \mathrm{kg}$, s.c.). When submitted to the carrageenan-induced peritonitis test, $\mathrm{ME}(0.5,1.0,2.0 \mathrm{~g} / \mathrm{kg}$, p.o. $)$ impaired leukocyte migration into the peritoneal cavity by $46.8,59.4$ and $64.8 \%$ respectively, while positive control dexamethasone ( $2 \mathrm{mg} / \mathrm{kg}$, s.c.), inhibited leukocyte migration by $71.1 \%$. These results indicate that the antinociception obtained after oral administration of methanol extract of $M$. lindleyana involves anti-inflammatory mechanisms accompanied with opioid-like activity which could explain the use of the specie for pain and inflammatory diseases.
\end{abstract}

\section{Introduction}

Mikania lindleyana DC., Asteraceae, is a creeper plant found in the Amazon region, known as sucuriju. The infusion of its leaves is empirically used as an anti-inflammatory, analgesic or cicatrizing and in the treatments of hepatitis, chronic gastric ulcers, varicose veins, acne and various types of cutaneous eruptions. Also is used as a diuretic and anti-hypertensive medication through orally administration of the tea leaves. The dry leaves of sucuriju are sold in some of Belém do Pará markets for medicinal purposes (Berg, 1993; Martins et al., 2005). The genus Mikania Willd belongs to the subtribe Mikaniinae and to the tribe Eupatorieae, from the family Asteraceae, and includes among 430 species across tropical regions.

Nowadays, several anti-inflammatory agents are used to treat different types of pain associated or not to the inflammatory process. These agents are efficient in most cases, but the collateral effects are common, especially when they are used in chronic treatments. The most common collateral effect is gastrointestinal disturb (Peura \& Goldkind, 2005). Considering the research of medicinal plants can propitiate the discovery of new molecules with innovative mechanisms or less adverse side effects (McCurdy \& Scully, 2005), the ethnopharmacological profile of Mikania lindleyana and the absence of phytochemical and pharmacological studies with the aerial parts of this plant, the aim of this work was to assess the antinociceptive and antiinflammatory activities and chemical studies of this specie. Here we report our first results of phytochemical and pharmacological investigations undertaken mainly with methanol extracts from the aerial parts of $M$. lindleyana. 


\section{Material and Methods}

\section{Extraction}

Mikania lindleyana DC., Asteraceae, aerial parts were collected in Benevides-PA (Brazil) and samples were identified by Dr. M. E. van den Berg, botanist from Emílio Goeldi Paraense Museum (MPEG). The voucher specimens were deposited at the João Murça Pires Herbarium of MPEG under MG-01607412 number.

Botanical material were dried and submitted to extraction with hexane at room temperature, followed by dichloromethane and methanol extraction. The solutions obtained were concentrated dry under reduced pressure in a rotary evaporator, below $40{ }^{\circ} \mathrm{C}$, to obtain the $n$-hexane (HE), dichloromethane (DME) and methanol (ME) extracts.

\section{Phytochemical characterization}

In the phytochemical study of $M$. lindleyana extracts, the substances were isolated by chromatographic methods and identified by usual spectroscopic methods (NMR, IR and MS) being detected in the hexane and dichloromethane extracts: stigmasterol $(0.27 \%$ of the extracts), stigmasta-4,24-dien-3-one $\quad(0.07 \%), \quad 24-$ methylene-cycloartan-3-ol $(0.60 \%)$, a mixture of $24-$ methylene-cycloartan-3-ol and cycloart-24-en-3-ol $(0.51 \%)$, a mixture of 24-methylene-cycloartan-3-one and cycloart-24-en-3-one $(0.29 \%)$, trans-phytol $(0.29 \%)$ and also long chain esters of stigmasterol $(0.57 \%)$ and fatty acids $(0.25 \%)$. A mixture of the inorganic salts $\mathrm{KNO}_{3}$ and $\mathrm{KCl}(0.50 \%)$ was obtained from the methanol extracts (Guilhon et al., 1998a,b,c, 1999).

When partitioned with water and chloroform, methanol extract $(1 \mathrm{~g})$ formed the aqueous $(\mathrm{A}-\mathrm{F})$ and chloroform (CH-F) fractions. Analyses by comparative thin layer chromatography (CCDC) on plates of silica gel $\left(\right.$ Merck $\left.\mathrm{F}_{254}\right)$ were eluted with butanol/acetic acid/ water (BAW, 4:1:5) and chloroform-methanol 9:1 $\left(\mathrm{CHCl}_{3}: \mathrm{MeOH}\right)$ and visualized in UV chromatograms at $254 \mathrm{~nm}$ and $366 \mathrm{~nm}$. The reagent NP/PEG (BAW) revealed the presence of flavonoids in $\mathrm{CH}-\mathrm{F}\left(\mathrm{R}_{\mathrm{f}} 0.70\right.$ and $0.57)$ and $A-F\left(R_{f} 0.20\right)$ for rutin and quercetin Rf $0.55 / R f$ 77 (Merck) and triterpenes (Liberman-Burchard) AF $\left(R_{f}\right.$ 0.21 and 0.27$)$. The Drangendorff reagent did not detect alkaloids (Moreira et al., 2008).

\section{Animals}

Adult male Swiss mice (25-35 g) were housed in plastic cages, with food and tap water available $a d$ libitum in the colony room. Mice were acclimatized to the laboratory for at least $60 \mathrm{~min}$ prior to the test procedure and were fasted for 12-18 $\mathrm{h}$ before the gavage. All experiments were carried out in accordance with current guidelines for the care of laboratory animals and the ethical guidelines on the use of animals in pain research (Zimmermann, 1986). The experimental protocols were approved by the local Animal Care and Use Committee (006/2006/CEPEB/UFRRJ). The minimum number of animals and duration of observation required to obtain consistent data were employed.

\section{Drugs}

Formalin, acetic acid, acetone (Merck AG, Darmstadt, Germany), indomethacin, carrageenan, naloxone hydrochloride (Sigma Chemical Co., St. Louis, MO, USA), fentanyl (Janssen Pharmaceutical), dexamethasone (Prodome, Brazil). The $n$-hexane (HE), dichloromethane (DME) and methanol (ME) extracts were prepared and provided by Dr. Giselle M. S. P. Guilhon (Federal University of Pará, Brazil). Test solutions of extracts and drugs were diluted in water (p.o.) or saline (s.c. or i.p.) in such a concentration as to allow the administration of constant volumes of $10 \mathrm{~mL} / \mathrm{kg}$ for each dose employed. The oral pre-treatment (p.o.) was always done $1 \mathrm{~h}$ and subcutaneous (s.c.) $30 \mathrm{~min}$ before tests.

\section{Acetic acid-induced writhing test}

In an initial screening of antinociceptive activity, group of six mice were orally treated with vehicle (water), $n$-hexane (HE), dichloromethane (DME), methanol (ME) extracts $(1.0 \mathrm{~g} / \mathrm{kg})$ or positive control indomethacin $(10$ $\mathrm{mg} / \mathrm{kg}), 60 \mathrm{~min}$ before acetic acid injection $(1.2 \%, 0.1$ $\mathrm{mL} / 10 \mathrm{~g}$ ) and the number of writhes was counted for the following $30 \mathrm{~min}$ (Koster et al., 1959). The absence of activity with the HE and DME directed the study to obtain in this method the dose effects of $\operatorname{ME}(0.1,0.3$ and $1.0 \mathrm{~g} / \mathrm{kg}$ ).

\section{Hot-plate test}

The latency (s) of heat stimulus $\left(55.0 \pm 0.5^{\circ} \mathrm{C}\right)$ was measured every $30 \mathrm{~min}$, starting $30 \mathrm{~min}$ before and up to 150 min after pretreatment of mice $(n=8)$ with vehicle (water), ME (300 mg/kg, p.o.), fentanyl (positive control - $100 \mu \mathrm{g} / \mathrm{kg}$, s.c. $), \mathrm{ME}+$ naloxone $(3 \mathrm{mg} / \mathrm{kg}$, s.c.) or fentanyl+naloxone. The animals whose basal flick responses were bigger than $9 \mathrm{~s}$ were discharged and a cutoff time of $30 \mathrm{~s}$ was maintained through the experiment, to prevent tissue damage. (D'Amour \& Smith, 1941).

\section{Formalin-induced nociception}

Groups of 6-8 mice were orally treated with water, ME $(300 \mathrm{mg} / \mathrm{kg})$, indomethacin $(10 \mathrm{mg} / \mathrm{kg}) 60$ min prior or fentanyl $(100 \mu \mathrm{g} / \mathrm{kg}$, s.c.) $30 \mathrm{~min}$ prior to 
injection of the formalin solution ( $3 \%, 20 \mu \mathrm{L} / \mathrm{paw}$, s.c.) into the plantar surface of the hind paw. To investigate the mechanism of antinociception, naloxone $(300 \mathrm{mg} / \mathrm{kg}$, s.c.) treatment preceded $(15 \mathrm{~min})$ the administration of ME or fentanyl. The time that animals spent licking the injected paw was measured with a chronometer and was considered as an index of pain (licking time) in seconds. From the formalin injection, the initial nociceptive response peaked at about 5 min (first phase) and was followed by a second peak (second phase) that occurred at 15-30 min post injection (Hunskaar et al., 1986; Hunskaar \& Hole, 1987).

\section{Peritonitis induced by carrageenan}

Mice $(n=10)$ were orally treated with vehicle (water), ME $(0.5,1.0$ and $2.0 \mathrm{~g} / \mathrm{kg}) 60 \mathrm{~min}$ prior to an injection of carrageenan ( $1 \%$ in saline; $250 \mu \mathrm{L} /$ mouse) into the peritoneal cavity. The positive control group was pre-treated $(30 \mathrm{~min})$ with dexamethasone $(2 \mathrm{mg} /$ $\mathrm{kg}$, s.c.). The number of leukocytes that had migrated to the peritoneum was counted in a Neubauer chamber and results were expressed as cells $\times 10^{6} / \mathrm{mL}$ and $\%$ of inhibition of leukocyte migration compared to control groups (Ferrándiz \& Alcaraz, 1991).

\section{Statistical analysis of data}

Data were statistically analyzed by one-way ANOVA followed by the Dunnet multicomparison test. In the hot-plate test, the two-way ANOVA followed by the Bonferroni's test analysis was used. The values are reported as mean \pm standard error of the mean (SEM). $\mathrm{P}$ values less than $0.05(p<0.05)$ were considered to be significant (Sokal \& Rohlf, 1981).

\section{Results}

\section{Acetic acid-induced writhing test}

The initial screening of antinociceptive activity demonstrated that the oral treatments with hexane (HE) or dichloromethane (DME) extracts $(1.0 \mathrm{~g} / \mathrm{kg})$ did not alter the number of acetic acid-induced abdominal writhing ( $48.3 \pm 3.9$ and $54.1 \pm 4.0$, respectively) compared to the control group $(51.3 \pm 3.8$ writhes) while as shown in Figure 1, methanol extract (ME - 0.1, 0.3 and $1 \mathrm{~g} / \mathrm{kg}$ ) produced a dose-related inhibition of acetic acid-induced abdominal writhing $(16.2 \pm 1.1,42.1 \pm 3.8$ and $70.2 \pm 4.8$ $\%$, respectively; IC $50=431.5 \mathrm{mg} / \mathrm{kg}$ ), . The group treated with indomethacin showed a decrease in accumulated abdominal writhes ( $14 \pm 2.5$ writes).

\section{Hot-plate test}

In the hot-plate test Figure 2 shows that the basal latency of control group was $7.1 \pm 0.6 \mathrm{~s}$ and orally administration of ME $(300 \mathrm{mg} / \mathrm{kg})$ increased the pain latency by $51.7 \pm 4.8,62.4 \pm 4.3,79.5 \pm 8.6$ and $33.8 \pm 1.7 \%$ after 30, 60, 90 and 120 min respectively. The positive control fentanyl $(150 \mu \mathrm{g} / \mathrm{kg}$, s.c. $)$ produced a significant increased of reactivity time to heat stimulus in the intervals between zero and $120 \mathrm{~min}$ with a maximum latency of 3.9-fold (30 $\mathrm{min})$. Pre-treatment (15 $\mathrm{min})$ with naloxone $(3 \mathrm{mg} / \mathrm{kg}$, s.c.) inhibited antinociceptive effect of ME (figure 2) and fentanyl (results no show).

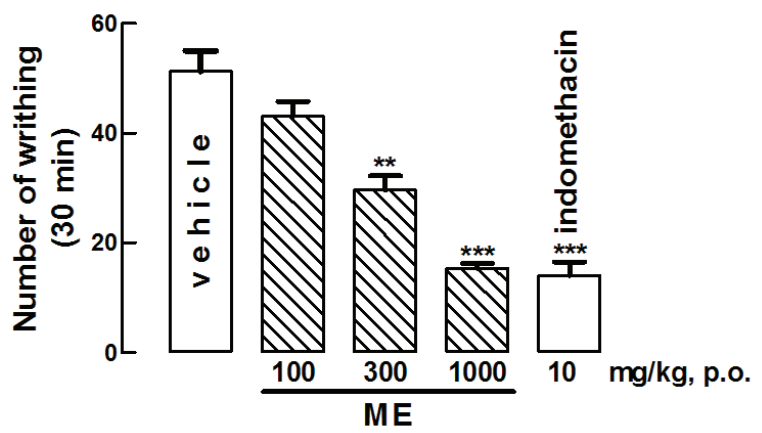

Figure 1. Effect of methanol extract (ME) obtained from the aerial parts of Mikania lindleyana or indomethacin on the acetic acid-induced writhing in mice. The vertical bars and lines express means \pm SEM of the number of writhing registered for $30 \mathrm{~min}$ after the acetic acid injection. Significantly different from vehicle group: ${ }^{* *} p<0.01 ; * * * p<0.001(\mathrm{n}=6)$.

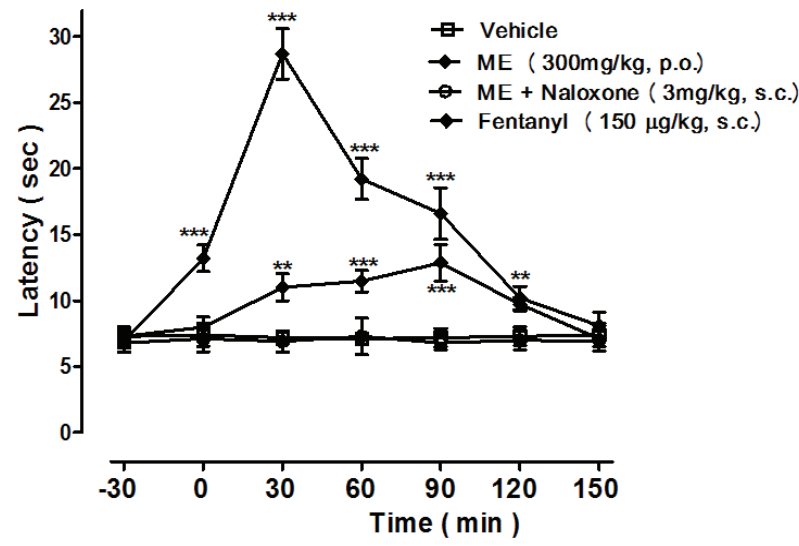

Figure 2. Latency of response to thermal stimulus (hot plate at $\left.55{ }^{\circ} \mathrm{C}\right)$ in group of mice $(\mathrm{n}=8)$ before and after treatment with water (Vehicle), methanol extract (ME) obtained from the aerial parts of Mikania lindleyana, fentanyl or ME+naloxone. The symbols and vertical lines express means \pm SEM of the latency for the nociceptive behavior. ${ }^{* *} p<0.01, * * * p<0.001$ when compared with the vehicle group. Symbols represent the different between the ME and fentanyl.

\section{Formalin-induced nociception}

In the formalin-induced nociception test, the 

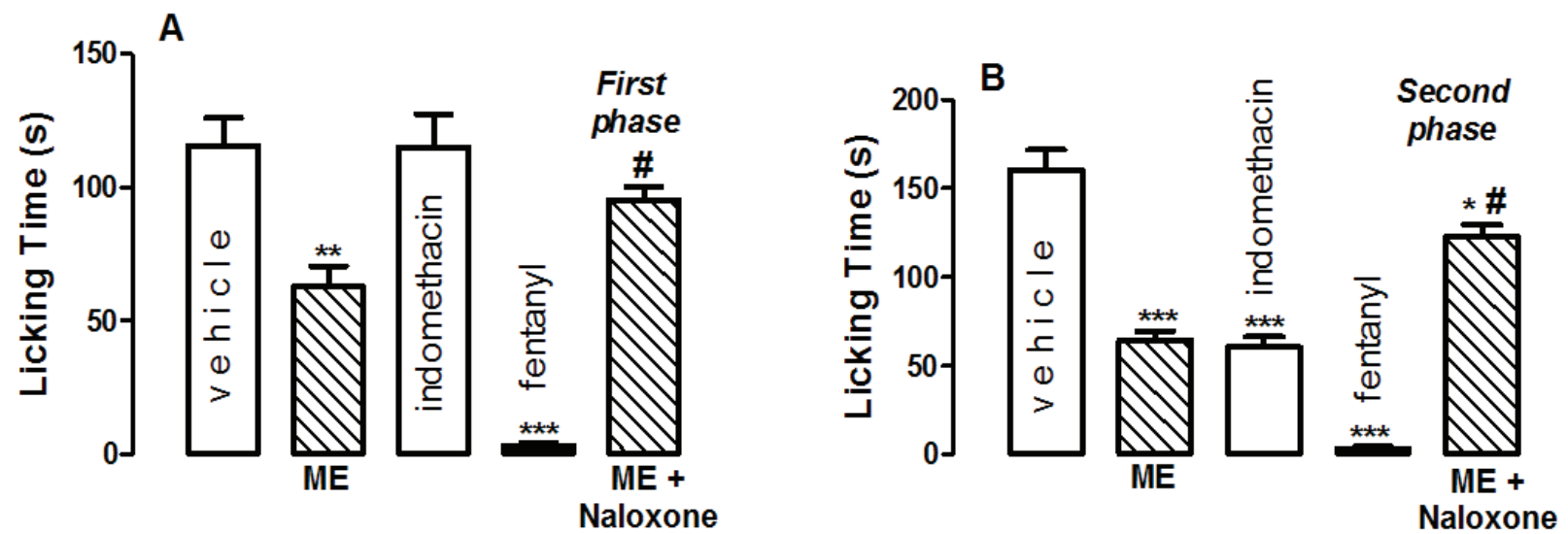

Figure 3. Effect of methanol extract of Mikania lindleyana (ME-300 mg/kg, p.o.) on the licking time (s) in the first phase (0-5 $\mathrm{min} / \mathrm{A})$ and second phase $(15-30 \mathrm{~min} / \mathrm{B})$ of the formalin test in mice $(\mathrm{n}=6-8)$. Fentanyl $(100 \mu \mathrm{g} / \mathrm{kg}$, s.c. $)$ and indomethacin $(10$ $\mathrm{mg} / \mathrm{kg}$, p.o.) were used as positive controls of the first and second phases respectively. The administration of naloxone (3 mg/ $\mathrm{kg}$, p.o.) preceded ME treatment. The vertical bars and lines express means \pm SEM of licking time. ${ }^{*} p<0.05, * * p<0.01 ; * * *$ $p<0.001$ significantly different from vehicle group (A-B) and \# $p<0.01$ when compared with the ME group (B).

licking time of animals previously treated with vehicle presented $115.8 \pm 10.3 \mathrm{~s}$ in the first phase and $160.5 \pm 11.4$ $\mathrm{s}$ in the second phase. ME $(300 \mathrm{mg} / \mathrm{kg}$, p.o. $)$ treatment produced reduction in pain reaction to $63.0 \pm 7.4 \mathrm{~s}$ (Figure $3 \mathrm{~A})$ and $64.1 \pm 5.5 \mathrm{~s}$ (Figure 3B) in the first and second phases respectively. The licking times of animals treated with fentanyl $(100 \mu \mathrm{g} / \mathrm{kg}$, s.c. $)$ were reduced in both phases (around 97\%), while indomethacin treatment (10 $\mathrm{mg} / \mathrm{kg}$, p.o.), a positive control of second phase, inhibited $62.3 \%$ this phase without influencing the first phase of nociception. The naloxone pre-treatment $(3.0 \mathrm{mg} / \mathrm{kg}$, s.c.) reversed totally the antinociceptive effects of ME in the first phase $(95.3 \pm 5.1 \mathrm{~s})$ and partially in the second phase $(122.6 \pm 7.2 \mathrm{~s})$ of test (Figures 3A and 3B). The fentanyl analgesic effect also were blocked by naloxone (results no show).

Table 1. Effect of ME of M. lindleyana on carrageenaninduced peritonitis in mice.

\begin{tabular}{lccc}
\hline \multicolumn{1}{c}{ Treatment } & $\begin{array}{c}\text { Dose } \\
(\mathrm{g} / \mathrm{kg})\end{array}$ & $\begin{array}{c}\text { Number of } \\
\text { leukocytes } \\
\left(\mathrm{x} 10^{6} / \mathrm{mL}\right)\end{array}$ & Inhibition (\%) \\
\hline Vehicle (p.o.) & - & $12.8 \pm 1.7$ & - \\
ME (p.o.) & 0.5 & $6.8 \pm 1.0^{* *}$ & 46.8 \\
ME (p.o.) & 1.0 & $5.2 \pm 0.8^{* * *}$ & 59.4 \\
ME (p.o.) & 2.0 & $4.5 \pm 0.9 * * *$ & 64.8 \\
Dexamethasone (s.c.) & 0.002 & $3.7 \pm 0.3^{* * *}$ & 71.1
\end{tabular}

Values represent the means \pm SEM of ten mice. Significantly different from vehicle group. $p<0.01, p<0.001$.

\section{Peritonitis induced by carrageenan}

Using carrageenan as a stimulus, it was possible to produce an acute inflammatory response after $4 \mathrm{~h}$ in the peritoneal cavity of mice, with a large number of leukocytes in the exudates. With the aim of evaluating a possible inhibitory effect of ME on the cell migration into the peritoneal cavity, the carrageenan-induced peritonitis test was used. As can be seen in Table 1 in comparison with vehicle group $\left(12.8 \pm 1.7 \times 10^{6}\right.$ leukocytes $\left./ \mathrm{mL}\right), \operatorname{ME}(0.5,1.0$ and $2.0 \mathrm{~g} / \mathrm{kg}$, p.o.) exhibited a dose-related reduction of leukocyte migration by $46.8,59.4$ and $64.8 \%$, respectively. The positive control dexamethasone $(2 \mathrm{mg} / \mathrm{kg}$, s.c. $)$ also was effective, inhibiting leukocyte migration by $71.1 \%$.

\section{Discussion}

In the antinociceptive screening using acetic acid-induced abdominal writhing model and high doses of hexane (HE), dichloromethane (DME) or methanol (ME) extracts obtained from the aerial parts of the Mikania lindleyana DC., Asteraceae, only the ME was effective. The writhing induced by acetic acid in mice result from chemical-induced a peripheral acute inflammatory reaction (Zakaria et al., 2006a). The treatment with ME promoted a dose-related antinociceptive effect in this model, normally used for screening of synthetic and natural compounds to determinate the presence of central and/or peripheral antinociceptive activity, because it is sensitive to nonsteroidal anti-inflammatory drugs (NSAID) and opioids (Zakaria et al., 2006b; Fischer et al., 2008). Moreover, the nociception induced in writhing method has been associated with some prostanoids, like as $\mathrm{PGE}_{2}, \mathrm{PGF}_{2 \alpha}$ and $\mathrm{PGI}_{2}$ (Deraedt et al., 1980) as well as lipoxygenase products (Ballou et al., 2000; Parveen et al., 2007), neurokinin A (Julia \& Buéno, 1997) and CGRP (Friese et al., 1997), for example. The consequence of the involvement of different mediators in the nociception, 
which means that based only on this model, is not possible to suggest any mechanism to the antinociceptive effect of ME.

Therefore the effectiveness of ME was tested in more two models of analgesia: hot-plate and formalininduced nociception tests. The hot plate test is a good model for studying central activity, being selectivity for drugs as opioid-derived analgesics. This assay is thought to involve the supraspinal reflex (Oliveira et al., 2008), produce an acute non-inflammatory nociception and moderate analgesic appear to have less or nothing effect in this kind of test (Zakaria et al., 2006a,b; Fischer et al., 2008). In this test, the ME affected mice latency time from the thermal stimulus, showing that ME antinociception may have the participation of central action. In fact, the reversal of this effect after prior administration of naloxone, a competitive antagonist of opioid receptors, reveled opioid-like mechanisms in the ME antinociception. This conclusion was reinforced by the results that $\mathrm{ME}$ reduced the licking time in the first phase (neurogenic pain) which is highly sensitive to opioid agents (Hunskaar \& Hole, 1987) and second phase (inflammatory pain) of formalin test. Additionally, naloxone also reversed antinociception produced of $\mathrm{ME}$ in both phases of the test. It has been demonstrated that intraplantar injection of formalin in rodents produces significant increases in spinal levels of different mediators, such as excitatory aminoacids, $\mathrm{PGE}_{2}$, nitric oxide and tachykinin, kinins, among other peptides (Fischer et al., 2008). The test produced a distinct biphasic nociceptive response generally regarded as the early (first) and late (second) phases. The early phase is result of direct stimulation of nociceptors by formalin and is an acute reaction observed immediately after the administration of the agent (0-5 min, tonic pain) (Zakaria et al., 2007). This phase is produced from stimulation of myelinated and unmyelinated fibers, mainly $\mathrm{C}$ fibers, and the release of substance $\mathrm{P}$, histamine, CGRP and can be suppressed by opioid analgesic drugs like morphine. (Gonçalves et al., 2008; Oliveira et al., 2008). Histamine appears to be the principal mediator in this phase (Wang et al., 2008). The second phase (15-30 min, localized inflammatory pain) is due to the inflammatory processes, with mediators release locally, such as prostaglandins, serotonin, histamine and bradykinin, as well as activation of the neurons located in the dorsal horns, which promote facilitation of synaptic transmission at the spinal cords (Oliveira et al., 2008; Zakaria et al., 2007). This latter phase was reported to be sensitive to the action of the majority of NSAID, including acetil salicilic acid, indomethacin or naproxen (Gonçalves et al., 2008) consequently the inhibition of the second phase suggest anti-inflammatory mechanism, although analgesics without anti-inflammatory properties such fentanyl, may exhibit this effect. The fact that naloxone reverse totally the first and partially the second phases suggest that ME antinociception is produced by anti-inflammatory and opioid-like mechanisms. The antinociception of ME is not related to nonspecific central effects, since no detectable effect was observed after oral administration of ME high dose in the rota-rod test (results not showed).

Considering the popular use of specie to treat inflammatory diseases and antinociception obtained in the second phase of formalin test accompanied by partial reversal with naloxone pre-treatment, the anti-inflammatory hypothesis was tested in leukocyte migration model. The carrageenan-induced peritonitis was used to investigate possible alterations in the leukocyte migration. ME reduced in a dose-related manner the total leukocyte migration to the peritoneum induced by carrageenan with a highest inhibition value by $64.8 \%$. This process is dependent of the synthesis and release of chemo-attractants such as lipoxygenase products and chemokines being constituted by three phase: leukocyte rolling, attachment and diapedesis. Drugs can reduce the leukocyte migration by inhibit the synthesis and release of chemo-attractants or by block of some leukocyte migration phase (Muller, 2002). Several studies have been reported that leukocytes migration would not be directly related to cyclooxygenase products, but the process could be inhibited by some, indicating that many mechanisms may be implicated in its control (Higgs et al., 1980; Mikami \& Miyasaka, 1983; Brooks \& Day, 1991). A recent study showed that $\mathrm{PGF}_{2 \alpha}$ was still able to induce leukocyte migration, suggesting that the inhibitory property of NSAID appears to be primarily related to the reduced production of the $\mathrm{PGF}_{2 \alpha}$ (De Menezes et al., 2005). Since several mechanisms may be involved in the leukocytes migration more studies must be done to elucidate the mechanism of the anti-inflammatory effect of ME.

These results showing that the oral administration of methanol extract of Mikania lindleyana produced a potent antinociceptive activity in the acetic acid-induced abdominal writhing, inhibitory effect on the reactivity of heat stimulus in the hot-plate test and the first phase (neurogenic pain) and second phase (inflammatory pain) of the formalin test with effects reversed by naloxone, are indicative that $\mathrm{ME}$ antinociception involves opioid-like mechanisms. The fact of ME also reduced the leukocyte migration, a characteristic activity present of anti-inflammatory drugs, allow to state that antinociception of ME is also associated with anti-inflammatory mechanisms.

The anti-inflammatory and antinociceptive effects of stigmasterol isolated from different vegetal species have been demonstrated in pharmacological models (Santos et al., 1995; Garcia et al., 1999) as flavonoids have long been recognized to possess a wide variety of biological activities such as antioxidant 
and anti-inflammatory (Middleton et al., 2000), besides the blockade of phospholipase $\mathrm{A}_{2}$, inhibit the cyclooxygenase and/or the lipoxygenase pathways of arachidonate metabolism (Lindahl \& Tagesson, 1997; Middleton et al., 2000; Kwak et al., 2003). Although the phytochemical study of hexane and dichloromethane extracts has detected stigmasterol compound (Guilhon et al., 1998a,b,c, 1999), high doses of these extractions were ineffective in acetic acid-induced writhing model, however the antinociceptive and anti-inflammatory activities of $\mathrm{ME}$ can be attributed to flavonoids compounds, such quercetin and rutin, present in this extraction (Moreira et al., 2008), without excluding the possibility of stigmasterol, and other chemical compounds present in the aerial parts of plant also participate in the analgesic and anti-inflammatory effectiveness of specie. These results could explain the use of the plant for pain and inflammatory diseases and a bioassay-guided fractioning of the extracts is now in progress to identify a greater number bioactive substances in aerial parts of $M$. lindleyana as well as the mechanisms of action involved in the effects described before.

\section{Acknowledgments}

The authors thank Carlos Chagas Filho Foundation for Research Support of Rio de Janeiro and Brazilian National Research Council for fellowships and financial support.

\section{References}

Ballou LR, Botting RM, Goorha S, Zhang J, Vane, JR 2000. Nociception in cyclooxygenase isozyme-deficient mice. Proc Natl Acad Sci USA 97: 10272-10276.

Berg MEVDE 1993. Plantas medicinais na Amazônia. Pará: Coleção Adolfho Ducke.

Brooks PM, Day RO 1991. Nonsteroidal anti-inflammatory drugs - differences and similarities. New Engl J Med 324: 1716-1725.

D'Amour FE, Smith DL 1941. A method for determining loss of pain sensation. J Pharmacol Exp Ther 72: 74-79.

Deraedt R, Jouquey S, Delevallee F, Flahaut M 1980. Release of prostaglandins $\mathrm{E}$ and $\mathrm{F}$ in an algogenic reaction and its inhibition. Eur J Pharmacol 61: 17-24.

De Menezes GB, Dos Reis WG, Santos JM, Duarte ID, De Francischi JN 2005. Inhibition of prostaglandin F(2alpha) by selective cyclooxygenase 2 inhibitors accounts for reduced rat leukocyte migration. Inflammation 29: 163-169.

Ferrándiz ML, Alcaraz MJ 1991. Antiinflammatory activity and inhibition of arachidonic acidmetabolism by flavonoids. Inflamm Res 32: 283-288.

Fischer LG, Santos D, Serafin C, Malheiros A, Monache FD,
Monache GD, Cechinel FV, Souza MM 2008. Further antinociceptive properties of extracts and phenolic compounds from Plinia glomerata (Myrtaceae) leaves. Biol Pharm Bull 32: 235-239.

Friese N, Diop L, Chevalier E, Angel F, Riviere PJ, Dahl SG 1997. Involvement of prostaglandins and CGRP dependent sensory afferents in peritoneal irritationinduced visceral pain. Regul Peptides 70: 1-7.

Garcia MD, Saenz MT, Gomez MA, Fernández MA 1999. Topical antiinflammatory activity of phytosterols isolated from Eryngium foetidum on chronic and acute inflammation models. Phytother Res 13: 78-80.

Gonçalves JCR, Oliveira FS, Benedito RB, Souza DP, Almeida RN, Araujo DAM 2008. Antinociceptive activity of carvone: Evidence of association decrease peripheral nerve excitability. Biol Pharm Bull 31: 1017-1020.

Guilhon GMSP, Miranda ACO, Muller AH, Brasil DSB 1998a. Derivados cicloartânicos de Mikania lindleyana (Compositae). 21 $1^{a}$ Reunião Anual da SBQ. Poços de Caldas, Brasil.

Guilhon GMSP, Teixeira UBA, Muller AH 1998b. Constituintes químicos dos extratos diclorometânico e metanólico de Mikania lindleyana (Compositae). Semana da Química 98 e I Encontro Paraense do Ensino de Química. Belém, Brasil.

Guilhon GMSP, Teixeira UBA, Brasil DSB, Maia JGS, Andrade EHA, Zoghbi MGB 1998c. Composição Química do Óleo Essencial de Mikania lindleyana DC. XXXVIII Congresso Brasileiro de Química. São Luiz, Brasil.

Guilhon GMSP, Brasil DSB, Muller AH, Marinho AMR 1999. Constituintes químicos dos extratos diclorometânico e metanólico de Mikania lindleyana A. DC. (Asteraceae). $22^{a}$ Reunião Anual da SBQ. Poços de Caldas, Brasil.

Higgs GA, Eakins KE, Mugridge KG, Moncada S, Vane JR 1980. The effects on non-steroid anti-inflammatory drugs on leukocyte migration in carrageenin-induced inflammation. Eur J Pharmacol 66: 81-86.

Hunskaar S, Berger OG, Hole K 1986. Dissociation between antinociceptive and antiinflammatory effects of acetylsalicylic acid and indomethacin in the formalin test. Pain 25: 125-132.

Hunskaar S, Hole K 1987. The formalin test in mice: dissociation between inflammatory and non-inflammatory pain. Pain 30: 103-114.

Julia V, Buéno L 1997. Tachykininergic mediation of viscerosensitive responses to acute inflammation in rats: evidence for a CGRP-induced release of tachykinins. Am J Physiol 272: 141-146.

Koster R, Anderson M, De Beer EJ 1959. Acetic acid for analgesic screening. Fed Proc 18: 412.

Kwak WJ, Moon TC, Lin CX, Rhyn HG, Jung HJ, Lee E, Kwon DY, Son KH, Kim HP, Kang SS, Murakami M, Kudo I, Chang HW 2003. Papyriflavonol A from Broussonetia papyrifera inhibits the passive cutaneous anaphylaxis reaction and has a secretory phospholipase A(2)- 
inhibitory activity. Biol Pharm Bull 26: 299-302.

Lindahl M, Tagesson C 1997. Flavonoids as phospholipase A2 inhibitors: importance of their structures for selective inhibition of group II phospholipase A2. Inflammation 21: 347-356.

McCurdy CR, Scully SS 2005. Analgesic substances derived from natural products (natureceuticals). Life Sci 78: 476-484.

Martins AG, Rosário DL, Barros MN, Jardim MAG 2005. Levantamento etnobotânico de plantas medicinais, alimentares e tóxicas da Ilha do Combu, Município de Belém, Estado do Pará, Brasil. Rev Bras Farm 86: 2130

Middleton JrE, Kandaswami C, Theoharides TC 2000. The effects of plant flavonoids on mammalian cells: implications for inflammation, heart disease, and cancer. Pharmacol Rev 52: 673-751.

Mikami T, Miyasaka K 1983. Effects of several antiinflammatory drugs on the various parameters involved in the inflammatory response in rat carrageenin-induced pleurisy. Eur J Pharmacol 95: 1-12.

Moreira SF, Guilhon GMSP, Müller AH, Rocha FF, Vanderlinde FA, Torres LMB 2008. Mikania lindleyana A. Dc.: Estudo Químico e Avaliação de Atividade biológica. XX Simpósio de Plantas Medicinais do Brasil - X International Congress of Ethnopharmacology. São Paulo, Brasil

Muller WA 2002. Leukocyte-endothelial cell interactions in the inflammatory response. Lab Invest 82: 521-533.

Oliveira FS, Sousa DP, Almeida RN 2008. Antinociceptive effect of hydroxydihydrocarvone. Biol Pharm Bull 31: 588-591.

Parveen Z, Deng Y, Saeed MK, Daí R, Ahamad W, Yu YH 2007. Antiinflammatory and analgesic activities of Thesium chinese Turcz extracts and its major flavonoids, kaampferol and kaempferol-3-O-glucoside. Yakugaku Zasshi 127: 1275-1279.

Peura DA, Goldkind L 2005. Balancing the gastrointestinal benefits and risks of nonselective NSAIDs. Arthritis
Res Ther 7 (Suppl 4): S7-S13.

Santos ARS, Niero R, Cechinel FV, Yunes RA, Pizzolatti MG, Delle Monache F, Calixto JB 1995. Antinociceptive properties of steroids isolated from Phyllanthus corcovadensis in mice. Planta Med 61: 329-332.

Sokal RR, Rohlf FJ 1981. Biometry: The Principle and Practice of Statistics 2. ed. New York: W.H. Freeman.

Wang JR, Zhou H, Jiang ZH, Wong YF, Liu L 2008. In vivo antiinflammatory and analgesic activities of a purified saponin fraction derived from the root of Ilex pubescens. Biol Pharm Bull 31: 643-650.

Zakaria ZA, Gopalan HK, Zainal H, Pojan NHM, Morsid NA, Aris A, Sulaiman MR, 2006a. Antinociceptive, antiinflammatory and antipyretic effects of Solanum nigrum Chloroform extract in animal models. Yakugaku Zasshi 126: 1171-1178.

Zakaria ZA, Abdul Ghan DF, Raden Mohd RNS, Gopalan HK, Sulaiman MR, Abdullah FC 2006b. Antinociceptive and antiinflamatory activities of Dicranopteris linearis leaves clhoroform extract in experimental animals. Yakugaku Zasshi 126: 1197-1203.

Zakaria ZA, Sulaiman MR, Gopalan HK, Abdul Ghani ZDF, Raden Mohd RNS, Mat Jais AM, Abdullah FC 2007. Antinociceptive and antiinflamatory properties of Corchorus capsularis leaves clhoroform extract in experimental animals models. Yakugaku Zasshi 127: 359-365.

Zimmermann M 1986. Ethical considerations in relation to pain in animal experimentation. Acta Physiol Scand 554: 221-223.

\section{*Correspondence}

Frederico A. Vanderlinde

Laboratório de Farmacologia, Sala 31, Pavilhão de Química, Universidade Federal Rural do Rio de Janeiro BR 465, km 07, 23890-000, Seropédica, RJ, Brazil vanderlinde@ufrrj.br Tel: +552126823222 